\title{
(China's Agriculture "Going Out" Strategy aße beyond Resource Constraints and Unbalanced Resench Holves Trading
}

\author{
Monzur Morshed \\ Faculty Member, Department of Economics, Comilla University, Comilla, BANGLADESH \\ *E-mail for correspondence: morshed_bau@yahoo.com
}

Received: July 25, 2017;

Accepted: Dec 01, 2017;

Published: Jan 18, 2018

Source of Support: Nil

No Conflict of Interest: Declared

\begin{abstract}
Implementation of agricultural "going out" strategy is the effective way to co-ordinate the use of international and domestic markets and resources, and to expand the breadth and depth of Agriculture in China. With the continual increase of industrialization and urbanization, agricultural production in China is conditioned by the limitation of cultivated land resources and fresh water resources, also impacted by exhaustion of soil, by frequent drought and floods. At the same time, China's agriculture trade also faces unbalanced situation and unfair international environment. Therefore, accelerating the implementation of the agriculture "going out" strategy, not only can effectively break through the bottleneck of agricultural development in the constraint of resources, get out of market monopoly from international agricultural multi-national companies, but also can give full play to advantages of our foreign exchange reserves to ensure the (supply effectiveness) of agricultural products in China. However, at present China's agriculture "going out" strategy hasn't got significant achievements, there are some problems such as slow growth in foreign investment in agriculture, regional centralization of investment, the small quantities and small scale of investment companies, and the lack of international agricultural professionals. For these reasons, the relevant government departments should increase financial support to encourage agricultural enterprises "going out"; speed up the training of professionals to create giant agricultural transnational corporations, resulting in occupying reasonable seats in global agricultural supply chain, and establishing China as resourceful agricultural trading nations.
\end{abstract}

Keywords: Agriculture "Going Out", Resource Constraints, Trading Environment

\section{INTRODUCTION}

Since the reform and opening to the world, China's agriculture has made a rapid development. China uses less than $4 \%$ of the world's arable land to feed more than $25 \%$ of the world's population. China's agriculture has been played an important role in achieving stable and rapid economic growth in the country, not only largely meet the growing needs of domestic more than 1.3 billion people's life under ensuring the effective supply of major agricultural products, but also effectively promote the development of the service of food and drink, textile and garments, agricultural processing and related industries. While developing export-oriented agriculture, carrying out the international economic and technical cooperation, China's agriculture has also made a huge contribution to the development of the world's agriculture and economy. However, the constraints and potential disadvantages which restricted the development of China's agriculture gradually highlighted, with the increases of industrialization and urbanization level of China's economy. In one hand, lack of arable land resources, and scarcity of water, restricts the long-term development of China's agriculture, on the other hand, decreased soil organic quality, regional drought severely affect the productivity of China's agriculture. Furthermore, China's agriculture is now facing the great challenges of dual pressures both in domestic and overseas under the background of the accelerating economic globalization, the deepening of division in agricultural production and the growing monopoly in global layout of agricultural supply chain. Therefore, accelerating China's agriculture "going out" step, making full use of domestic and foreign markets, achieving optimal allocation of resources at home and abroad, is China's best way to develop agricultural production, to effectively break the bottleneck of constrained resources, and to take up reasonable status in the global agricultural supply chain.

There are less than 10 years for fully implementation of China's agriculture "going out" strategy. Before joining the World Trade Organization, China cooperated with foreign 
countries mainly in "bringing in" agricultural technique or FDI. After entering into the WTO, China's agriculture has entered a stage of full opening to the world with the combination of "bringing in "and "going out". In 2007, China first proposed the policy of "speeding up the implementation of agriculture 'going out' strategy" which clearly stated that "supporting agricultural export enterprises to register brand in foreign markets, to carry out overseas market research, to promote marketing activities". Indeed, there are some different views in domestic scholars on agriculture should or how to "go out". Agriculture "going out " is facing an un-liberal environment of foreign investment, financing difficulties, the lack of insurance policies and other constraints , also facing some country's risk such as political risk, financial risk and economic risk, etc. . However, under the background of increasingly deepening of economic globalization, acceleration of national industrial restructuring and flowing of factors of production in every country, the degree of agricultural internationalization continuously increases the situation of exploiting international agricultural resources is severe day by day and the competition is becoming intense. A prominent feature of current agricultural internationalization is significantly enhanced of dominant role of multinational agricultural, and the multinational companies are profoundly changing the international division of work and agricultural trade patterns, Therefore, rightly grasping the opportunities and challenges of agricultural internationalization, it will be asses how to speeding up the implementation of agriculture "Going Out" strategy is an important measure to improve the international competitiveness of China's agriculture, especially to ensure China's food security.

\section{Serious Constraints of China's Agricultural RESOURCE}

\section{Lack of arable land resources}

Since the reform and opening, China's grain production has made remarkable achievements. From 1978 to 2010, China's grain output jumped from 300 million tons to 550 million tons, an increase of $83.3 \%$; grain yield from 168.7 $\mathrm{kg}$ per $\mathrm{mu}(\mathrm{Mu}$ is the Chinese Measuring unit. Where $1 \mathrm{Mu}$ $=0.067$ Hectare) in 1978 , increased to $331.5 \mathrm{~kg}$ per $\mathrm{mu}$ in 2010, an increase of $96.5 \%$; food possession per capita increased from $318.7 \mathrm{~kg}$ in 1978, to $407.5 \mathrm{~kg}$ (Calculated using the data of China's 2010 statistical bulletin) in 2010, exceeded the world average of $350 \mathrm{~kg}$ per capita. To some extent, the progress of China's grain production has also made a great contribution to the development of the world's agriculture and the world's economy. However, China's agriculture is facing now a grim situation of land shortage and gradually declining arable land. It's cultivated land area reduced from 1951 million mu in 1996 to 1826 million mu in 2007 (China Statistical Yearbook 2010 shows the data of arable land stated by the China's Ministry of Land and Resources in 2008), 125 million mu of cultivated land had decreased within 11 years, annually reduction was up to 11.36 million mu. According to FAO, China's arable land was only 16.3 Million $\mathrm{mu}$ in 2008 (http:/ / faostat.fao.org/site/377/DesktopDefault.aspx?Pa geID=377\#ancor).

\section{Lack of freshwater resources}

China's total freshwater is currently only 2.8 trillion cubic meters, accounted for $6.5 \%$ of the 43.4 trillion cubic meters in the world's. The possession of freshwater per capita in China is only about 2121 cubic meters, equivalent to $29.5 \%$ of the world average level [Calculated using the data of FAO "REVIEW OF WORLD WATER RESOURCES BY COUNTRY"

(http://www.fao.org/nr/water/aquastat/dbases/index.st $\mathrm{m}$.), where the possession of water resources per capita in the world is equal to 7,185.32 cubic meters(43.4 trillion cubic meters / 60.4billion population); China's the possession of water resources per capita in China is equal to 2121.21 cubic meters (2.8 trillion cubic meters / 1.32 billion population).].

For a long time, the proportion of China's agricultural water consumption to the total has remained at $60 \%$ (see Table 1). With the continuous development of China's economy, and rigid growth of demand for freshwater resources, serious shortage of freshwater resources will certainly affect China's agricultural production and food security, if no effective measures are taken to ensure sufficient freshwater resources in China.

Table 1 China's water consumption, 1997-2009

\begin{tabular}{|c|c|c|c|c|c|c|c|}
\hline \multirow{3}{*}{ Year } & \multicolumn{3}{|c|}{$\begin{array}{c}\text { Water Consumption } \\
(100 \text { million cubic meters })\end{array}$} & \multicolumn{3}{c|}{$\begin{array}{c}\text { The proportion of total } \\
\text { water consumption (\%) }\end{array}$} \\
\cline { 2 - 8 } & living & $\begin{array}{c}\text { Indus } \\
\text { try }\end{array}$ & $\begin{array}{c}\text { Agricul } \\
\text { ture }\end{array}$ & Total & Living & $\begin{array}{c}\text { Indus } \\
\text { try }\end{array}$ & $\begin{array}{c}\text { Agricul } \\
\text { ture }\end{array}$ \\
\hline 1997 & 525 & 1121 & 3920 & 5566 & 9.43 & 20.4 & 70.43 \\
\hline 1998 & 543 & 1126 & 3766 & 5435 & 9.99 & 20.72 & 69.29 \\
\hline 1999 & 563 & 1159 & 3869 & 5591 & 10.07 & 20.73 & 69.20 \\
\hline 2000 & 575 & 1139 & 3784 & 5498 & 10.46 & 20.72 & 68.83 \\
\hline 2001 & 600 & 1142 & 3826 & 5567 & 10.78 & 20.51 & 68.73 \\
\hline 2002 & 619 & 1143 & 3736 & 5497 & 11.26 & 20.79 & 67.96 \\
\hline 2003 & 633 & 1176 & 3436 & 5320 & 11.90 & 22.11 & 64.59 \\
\hline 2004 & 653 & 1228 & 3589 & 5548 & 11.77 & 22.13 & 64.69 \\
\hline 2005 & 677 & 1284 & 3583 & 5633 & 12.02 & 22.79 & 63.61 \\
\hline 2006 & 696 & 1343 & 3667 & 5795 & 12.01 & 23.18 & 63.28 \\
\hline 2007 & 713 & 1403 & 3601 & 5819 & 12.25 & 24.11 & 61.88 \\
\hline 2008 & 727 & 1377 & 3620 & 5828 & 12.47 & 23.63 & 62.11 \\
\hline 2009 & 750 & 1388 & 3687 & 5933 & 12.64 & 23.34 & 62.14 \\
\hline
\end{tabular}

Source: 1997-2007 data from the Bulletin of Water Resources 1997-2007(China's Ministry of Water Resources), 2008-2009 data from the "The Statistical Bulletin of National Water Resources Development "(2008, 2009), Ministry of Water Resources, China.

\section{Degradation of soil quality}

China is now facing the problem of serious land pollution and degradation of land quality due to over-using chemical fertilizers, pesticides, plastic film and other chemical products, and also due to high index of replant and non-recuperation of the land. For example, major grain producing areas of Hebei, Henan, Hunan, Zhejiang, Anhui 
and other provinces, have suffered different degrees of soil ossifying and compacting, unbalanced nutrient, becoming shallow and declining functions of keeping water and fertilizer and so on which seriously affecting agricultural productivity. The author have been to the main areas producing cotton in Xinjiang and found that the long pursuit of the high cotton yield resulting in a more serious environmental pollution due to extensive use of drip irrigation under plastic film, defoliant and other chemical products. According to the survey, the average residual film is about $5.99 \mathrm{~kg}$ per $\mathrm{mu}$ in the cotton fields which has been continuously cultivated for 3 to 5 years; about $12.6 \mathrm{~kg}$ per mu after 8 or 10 years. Most area in Xinjiang has been using the plastic film over 20 years, and residual film has caused great harms to some cotton fields. Chemical fertilizers, pesticides, defoliants are used year by year, resulting in difficulties in moisture conservation of cotton soil, increasing salinization and so on. Therefore, degradation of soil quality has become another bottleneck to the development of China's agriculture.

Unbalanced agricultural trade and unfair international competition

The deficit of China's agricultural trade has been enlarging yearly: Since 2004, the first deficit in China's agricultural trade emerged, and the deficit has shown a trend of expansion (Table 2). In 2010, the deficit of China's agricultural trade reached 23.04 billion U.S. dollars, an increase of 9.97 billion U.S. dollars and of $76.28 \%$ compared with 2009. While in the main imports of agricultural products, soybean trade deficit reached 24.96 billion U.S. dollars, cotton trade deficit reached 5.65 billion U.S. dollars, and edible oil trade deficit reached 6.71 billion U.S. dollars. The forecasting can be seen that the deficit of China's agricultural trade will further increase, together with the increasing demand for cotton, edible vegetable oil and soybeans, along with the constantly development of China's economy and the improvement of living standards.

Table 2: China Agricultural Foreign Trade, 2000-2010 Unit: 100 million U.S. dollars

\begin{tabular}{|c|c|c|c|c|}
\hline Year & Export & Import & Total Amount & Net Export \\
\hline 2000 & 157.0 & 112.7 & 269.7 & 44.3 \\
\hline 2001 & 160.9 & 118.5 & 279.4 & 42.4 \\
\hline 2002 & 181.6 & 124.7 & 306.3 & 56.9 \\
\hline 2003 & 213.3 & 189.7 & 403.0 & 23.5 \\
\hline 2004 & 233.9 & 280.5 & 514.4 & -46.5 \\
\hline 2005 & 276.0 & 287.8 & 563.8 & -11.8 \\
\hline 2006 & 314.2 & 321.7 & 636.0 & -7.5 \\
\hline 2007 & 339.0 & 411.9 & 750.9 & -72.9 \\
\hline 2008 & 405.4 & 587.9 & 993.3 & -182.5 \\
\hline 2009 & 396.3 & 527.0 & 923.3 & -130.7 \\
\hline 2010 & 488.7 & 719.1 & 1207.8 & -230.4 \\
\hline
\end{tabular}

Source: Agricultural imports and exports data(2000-2009) is from the official website of the China Ministry of Agriculture; data of 2010 year is from the Ministry of
Commerce, "Monthly Statistical Report of China Import and Export of Agricultural Products", February 2010.

China has a higher degree of openness for agricultural market: After Joining the World Trade Organization (WTO), China has been actively fulfilling the commitments, constantly opening the markets for agricultural products. At present, China's average tariff rate on agricultural imports has been decreased to $15.7 \%$ (Table 3), ranked No. 17 in the 148 WTO members, almost the same as the openness of the European Union, Canada and other developed countries, while the world average agricultural import tariff rate is up to $57.6 \%$, India's agricultural import tariff rate is up to $113.1 \%$ and Brazil has reached $35.4 \%$.It can say that China has the highest degree of openness for agricultural imports in all of the Third World countries. Even compared with some developed countries such as Norway, Japan, Singapore, China's agricultural products is also very high degree of openness.

Table 3: The average tariff rate of agricultural imports in the world and major countries, 2009, (Unit \%)

\begin{tabular}{|c|c|c|c|c|c|c|c|}
\hline Country/ & $\begin{array}{c}\text { Tariff } \\
\text { Rate }\end{array}$ & $\begin{array}{c}\text { Country/ } \\
\text { Region }\end{array}$ & $\begin{array}{l}\text { Tariff } \\
\text { Rate }\end{array}$ & $\begin{array}{c}\text { Country/ } \\
\text { Region }\end{array}$ & $\begin{array}{l}\text { Tariff } \\
\text { Rate }\end{array}$ & $\begin{array}{l}\text { Country/ } \\
\text { Region }\end{array}$ & $\begin{array}{c}\text { Tariff } \\
\text { Rate }\end{array}$ \\
\hline $\begin{array}{c}\text { Average of } \\
\text { the world }\end{array}$ & 57.6 & Egypt & 95.4 & $\begin{array}{c}\text { South } \\
\text { Africa }\end{array}$ & 39.5 & Vietnam & 18.5 \\
\hline Bangladesh & 192.0 & Israel & 73.3 & Cuba & 37.0 & $\begin{array}{c}\text { Chinese } \\
\text { Taipei }\end{array}$ & 17.4 \\
\hline Nigeria & 150.0 & Malaysia & 73.0 & Brazil & 35.4 & China & 15.7 \\
\hline Norway & 130.9 & Korea & 56.1 & Philippines & 35.0 & Canada & 15.4 \\
\hline India & 113.1 & $\begin{array}{c}\text { Switzer } \\
\text { land }\end{array}$ & 48.0 & Argentina & 32.4 & $\begin{array}{c}\text { European } \\
\text { Union }\end{array}$ & 13.5 \\
\hline Iceland & 109 & Indonesia & 47.1 & Singapore & 27.3 & $\begin{array}{c}\text { New } \\
\text { Zealand }\end{array}$ & 5.9 \\
\hline Kuwait & 100 & Mexico & 44.2 & Japan & 22.2 & USA & 5.2 \\
\hline Pakistan & 95.6 & Thailand & 40.6 & Mongolia & 18.9 & Australia & 3.4 \\
\hline
\end{tabular}

Source: WTO official website, 2010

Developed countries pay huge amount of subsidies to agriculture: Subsidies are the main policy for many Countries to support and protect agricultural production. OECD statistics (Data from the OECD website database) show that in 2009 the U.S. subsidies to agriculture (the producer subsidy equivalents, Producer Support Estimate, PSE) amounted to 30.6 billion U.S. dollars, accounting for $10.7 \%$ of the total value of agricultural production; EU's agricultural subsidies was 86.98 billion Euros, accounting for $28.6 \%$ of the total value of agricultural production; Canada, Japan, South Korea, Switzerland, Norway, had the amount of subsidies to agriculture accounts for the proportion of agricultural GDP, respectively, $22.1 \%, 51.7 \%, 54 \%, 92.2 \%, 101.7 \%$; the amount of agricultural subsidies in Russia had reached $11.4 \%$ of its agricultural GDP, while China in 2009, the subsidies given to agricultural production was only 446.82 billion Yuan, accounting for $7.4 \%$ of agricultural GDP. Compared to the United States, Canada and other developed countries and regions, the level of agricultural subsidies in China is relatively low. Even compared to Russia, Korea, Turkey, Mexico and other developing 
countries, the amount of agricultural subsidies is very small. To some extent, developed countries' huge agricultural subsidies, especially America's, are significantly enhancing the international competitiveness of its agricultural products. Data show that the United States in 2008 gave 1.48 billion U.S. dollars of subsidies to cotton, and then the output value of cotton was 3.7 billion U.S. dollars, with subsidies accounted for $40 \%$ of cotton output; in 2008 U.S. soybean subsidies amounted to 1.75 billion U.S. dollars, then the output value of soybean was 29.58 billion U.S. dollars, the amount of subsidy accounted for $6 \%$ of the soybean output value. In 2008 , China's imports of cotton and soybeans from the United States were 0.99 million tons $(46.8 \%$ of total imports), 15.43 million tons ( $41.2 \%$ of total imports), imports amounted to 1.66 billion U.S. dollars (accounting for $47.6 \%$ of the total value of imports), 8.43 billion U.S. dollars (accounting for $38.6 \%$ of the total value of imports). It could be said that the United States and other developed countries reduce their agricultural production costs by the huge agricultural subsidies. Although in the short term it can meet China's effective demand for cotton, soybeans and other agricultural products, , but in the long run, under the huge U.S. subsidies, cotton, Soybeans and other agricultural products from the United States will seriously affect the competitiveness, and even production of some agricultural products in China.

Table 4: GDP, Agricultural Production Value and Agricultural Subsidies of different Countries, 2009

\begin{tabular}{|c|c|c|c|c|c|c|}
\hline Item Country or Region & USA & European & Canada & $\begin{array}{c}\text { Switzer } \\
\text { land }\end{array}$ & Norway & Iceland \\
\hline Agricultural Production Value & 2870.2 & 3036.7 & 402.8 & 73.1 & 229.4 & 199.3 \\
\hline Subsidies & 306 & 869.8 & 89 & 67.4 & 233.4 & 142.2 \\
\hline $\begin{array}{c}\text { The Share of Subsidy in } \\
\text { Agricultural Production Value }\end{array}$ & $10.7 \%$ & $28.6 \%$ & $22.1 \%$ & $92.2 \%$ & $101.7 \%$ & $71.4 \%$ \\
\hline Country or Region & Japan & Korea & Russia & Turkey & Mexico & China \\
\hline Item Agricultural Production Value & 84.2 & 413737 & 17668.3 & 904028.3 & 5767.1 & 60361 \\
\hline Subsidies & 43.5 & 223342 & 2015.7 & 349635.2 & 786.1 & 4468.2 \\
\hline $\begin{array}{c}\text { The Share of Subsidy in } \\
\text { Agricultural Production Value }\end{array}$ & $51.7 \%$ & $54 \%$ & $11.4 \%$ & $38.7 \%$ & $13.6 \%$ & $7.4 \%$ \\
\hline
\end{tabular}

Note: The unit of measurement is the national currency in each country or region respectively, such as 100 million Euros of European Union, 100 million USD in U.S., 100 million RMB in China; Brazilian data are that in 2007

Source: China's agricultural production value are from Chinese Statistic Yearbook (2010), the data of China's agricultural subsidies derived from WANG Ying-hui: "Significant increase in the financial sector fund for agriculture" Economic Information Daily, March 11, 2009.Other Countries 'data are from OECD database.

\section{The Situation of China's Agriculture "Going Out" DeVelopment}

China's investment in foreign agriculture has been increasing year by year, but with lower growth

China's investment to foreign country's agriculture has made a great development after joining WTO. From 2004 to 2009, China's agricultural foreign investment flows increased from 289 million to 343 million USD, an increase of $18.6 \%$, and the foreign investment stock increased from 834 million to 2.03 billion USD, an increase of 1.43 times (Table 5). Besides, the region of China's agricultural foreign investment is also enlarging, not only in Asia, particularly in ASEAN countries, but also in the U.S., EU and other developed countries and regions. However, compared with the total foreign investment at the same period, China's agricultural growth rate of foreign investment has lagged noticeably. From 2004 to 2009, The total flows and stock of China's agricultural foreign investment increased respectively by 9.28 times from 5.50 billion to 56.53 billion USD, and by 4.5 times from 44.78 billion to 245.76 billion USD. Moreover, the ratio of agricultural foreign investment to total foreign investment has been declined from 2004 to 2009 . The ratio of flows declined from $5.25 \%$ to $0.61 \%$, and the one of stock fell from $1.86 \%$ to $0.83 \%$.

Table 5 China's agricultural foreign investment flows, stocks and its share to the total amount of China's foreign investment (unit: 100, million USD)

\begin{tabular}{|c|c|c|c|c|c|c|c|}
\hline Item & year & 2004 & 2005 & 2006 & 2007 & 2008 & 2009 \\
\hline \multirow{3}{*}{ flows } & $\begin{array}{c}\text { foreign investment in } \\
\text { agriculture }\end{array}$ & 2.89 & 1.05 & 1.85 & 2.72 & 1.72 & 3.43 \\
\hline & $\begin{array}{l}\text { total amount of China's } \\
\text { foreign investment }\end{array}$ & 54.98 & 122.61 & 211.64 & 265.06 & 559.07 & 565.29 \\
\hline & $\begin{array}{c}\text { The Ratio of Agricultural } \\
\text { Investment }\end{array}$ & $5.25 \%$ & $0.86 \%$ & $0.87 \%$ & $1.03 \%$ & $0.31 \%$ & $0.61 \%$ \\
\hline \multirow{3}{*}{ stocks } & $\begin{array}{c}\text { foreign investment in } \\
\text { agriculture } \\
\end{array}$ & 8.34 & 5.12 & 8.17 & 12.06 & 14.68 & 20.28 \\
\hline & $\begin{array}{c}\text { total amount of China's } \\
\text { foreign investment }\end{array}$ & 447.77 & 572.06 & 906.31 & 1179.11 & 1839.71 & 2457.55 \\
\hline & $\begin{array}{c}\text { The Ratio of Agricultural } \\
\text { Investment }\end{array}$ & $1.86 \%$ & $0.89 \%$ & $0.90 \%$ & $1.02 \%$ & $0.80 \%$ & $0.83 \%$ \\
\hline
\end{tabular}

Note: The concept of agriculture in the table refers to agriculture, forestry, animal husbandry and fishery.

Source: Statistical Bulletin of Foreign Direct Investment (2008, 2009), published by Ministry of Commerce, National Bureau of Statistics, the State Administration of Foreign Exchange.

China's investment in foreign agriculture is concentrative in short countries or regions

The region of China's investment for oversea agricultural foreign is relatively concentrative although the areas of investment are scattered over more than 30 countries and regions in Asia, Africa, North America, Europe and Oceania. Table 6 Shows, up to 2009, China had invested to Russia's and ASEAN's agriculture about 548 million USD and 341 million USD, accounted to $43.82 \%$ in total investment stock of 2.028 billion USD, in which, each region's share of investment accounted to $27.02 \%$ and $16.8 \%$ respectively. In 2009, China's foreign agricultural investment flow is 289 million USD in total, the share of Russia and ASEAN accounted to $52.57 \%$, in which investment in ASEAN's countries accounted to $32.27 \%$. On the contrary, 2009, China's agricultural investment in flow to EU and U.S. accounted for $16.84 \%$ and $4.71 \%$ respectively in the total agricultural investment flow, China's agricultural investment in stock to EU and U.S 
accounted to $9.7 \%$ and $1.48 \%$ in total agricultural investment stock, which means that China's agricultural investment to the developed countries and regions was relatively less. It also indicates that China's regional choice of agricultural foreign investment is the bordering areas, which satisfies the principle of comparative advantage in factors content. In one hand, Russia has rich and fertile land, whereas ASEAN owns low-cost labor resources; on the other hand, the short distance of Russia and ASEAN to China creates low transaction costs, especially the establishment of China - ASEAN Free Trade Area and the implementation of "Early Harvest Scheme" result in lower cost of imports between China and ASEAN. China's agricultural investment to ASEAN could forecast a further development as the full implementation of zero tariffs of China - ASEAN Free Trade Area after 2010. But it should be noted that excessive centralization on the investment regions may lead to an intensifying risk of China's agricultural foreign investment due to the instability of regional political and economy.

Table 6: China's agricultural investment in major countries and regions and its shares in 2009 unit: 10 thousand dollars

\begin{tabular}{|l|c|c|c|c|c|c|}
\hline Item & Total Amount & European Union & USA & Russia & ASEAN & Others \\
\hline Flow & 34279 & 5772 & 1615 & 6960 & 11061 & 8871 \\
\hline Share & $100 \%$ & $16.84 \%$ & $4.71 \%$ & $20.30 \%$ & $32.27 \%$ & $25.88 \%$ \\
\hline stock & 202844 & 19667 & 3006 & 54825 & 34054 & 91292 \\
\hline Share & $100 \%$ & $9.70 \%$ & $1.48 \%$ & $27.03 \%$ & $16.79 \%$ & $45.01 \%$ \\
\hline
\end{tabular}

Source: The same as Table 5

The enterprises in China to invest foreign agriculture are less, small scale and lack of Professionals

At present, China has formed 582 national leading enterprises in agricultural industrialization, and more than 50,000 medium agricultural enterprises, however, there are only about 40 agricultural enterprises invest directly in foreign countries, make joint venture or cooperate in any other ways [16]. From the total investment point of view, China's oversea agricultural investment in 2007 was 272 million USD (Table 5), accounted for $1.02 \%$ of total foreign direct investment; in 2008, China's overseas agricultural investment reduced to 172 million, the proportion dropped to $0.31 \%$; in 2009, China's overseas agricultural investment was up to 343 million, but the proportion dropped further to $0.61 \%$. Less number and small scale of enterprises to invest in foreign agriculture are the main features of China's agriculture "going out", so, China's agricultural enterprises in foreign countries could not be able to compete with huge multinational companies. In addition, China's oversea agricultural enterprises are general lack of professionals who are familiar with the regulation of international investment, international finance, international trade, as well as the policies, language and the custom of the country or region in which China's agricultural enterprises are invested, thus some investment projects could not implement smoothly, and even further development of oversea agricultural investment had been impeded.

\section{POLICY IMPLICATION}

China should make Macro-Guidance and planning for agriculture "Going Out" strategy

At present, China's agriculture "going out" strategy has made some achievements. In Southeast Asia, Russia, Africa and Central and South America countries, a number of food, natural rubber, sisal and other production bases has been established. Especially some countries such as Zambia, Mozambique, China has obtained a great success in agricultural investment. But, overall, China's agricultural foreign investment is still rare, and the scale of agriculture "going out" is still relatively small, so the macro-national plan is needed. Chinese government should give macro-guidance for agricultural enterprises to "going out", including countrylevel planning, industrial planning, and product-level planning, based on long-term objective for the economic and agricultural development. The cooperation of exploiting overseas agricultural resources should be planed scientifically. China should give priority to that overseas producing and developing land-intensive agricultural products or raw materials which industry needed urgently, such as cotton, soybean, corn and so on. Foreign investment in agriculture and agricultural labor export should be one of the major strategies in China for agricultural development and expansion of agriculture opening-up. Through the establishment of overseas farms or production bases, China could steady the supply channels of agricultural products, ensure the long-term supply of agricultural products, and maintain long-term sustainable and healthy development of the national economy.

\section{China should increase financial support and encourage agricultural enterprises"Going Out"}

China should actively explore and take the appropriate financial support policies to encourage those leading agricultural enterprises which have the ability to set up owned, joint ventures, or to carry out co-production, labor export and other forms in overseas agriculture to seek exploiting and constructing the overseas production bases of natural resources. China should set up special fund of agriculture "going out" in the budget to encourage and support qualified enterprises to develop foreign agricultural cooperation; or establish the "Foreign Agricultural Resource Development Fund" to provide subsidies for the predevelopment costs of the agricultural enterprises which may develop agricultural production in Africa and South America in order to offset the problem of longer cycle, higher risk and slower returns of investment.

\section{China should improve the agricultural insurance system}

Agricultural production faces many great risks in nature and market, particularly for the overseas agricultural enterprises, which lack domestic policy support and worry about huge uncertainty of agricultural income. So, any agricultural enterprise is highly sensitive to the risk of production. The Government should establish a mechanism assessing the risk for agriculture "going out". The special insurance terms covering agricultural foreign investment should be set up. The stage of accepting insurance for agriculture exports should cover from the export declaration to the producing and 
breeding stage. The coverage of accepting insurance should also be expanded, and the premium subsidies should be further increased.

In addition, some national banks, such as the Export-Import Bank of China, the Bank of China Agricultural Development should safeguard the successful implementation of the agriculture "going out" strategy, through issuing a large number of low-interest loans and the financial support insurance together with its corresponding professional assistance and services, so as to reduce the costs of "going out", distribute and remove the agricultural risks, and to improve the overall competitiveness of China's agriculture. Commercial banks should liberalize the condition of agriculture financing in order to help agricultural enterprises to solve the financing difficulties.

\section{China should encourage agriculture "Going Out" diversified development}

Firstly, China should encourage agricultural enterprises to select the targeted market for "Going Out" in diversification, continuously strengthen and expand the market which has been made in a certain scale in Russia, Korea, Southeast Asia and other traditional investment market, further develop the market in Africa, Latin America and other developing markets, but also research and develop the European and American markets in depth. Secondly, China should encourage the "going out" agricultural enterprises to produce in diversified modes, not only cooperating in a single model of investment, but also seeking technological or professional cooperation. The "going out" agricultural enterprises should actively develop the projects with deep processing, high value-added and finished machining to improve the technological content of products, to extend the industrial chain so as to achieve the benefits of scale. Thirdly, China should encourage "going out" agricultural enterprises cooperate with other country in diversified patterns, such as development of specialty, joint research, etc. The "going out" agricultural enterprises should actively cooperate with other countries in the variety, capital, technology, management and marketing and other aspects, in order to solve the bottleneck of resource-shortage by "going out" strategy, while bringing advanced agricultural technology and management style from other countries into the domestic agricultural production.

\section{At Last}

Chinese government should strengthen the professional training in order to get the inter-disciplinary talent, in the international trade of agricultural products and multinational business management using domestic agricultural educational resources to carry out multi-language training, especially minority language, so as to relief the lack of multinational producing and trading agricultural products as soon as possible. China should also foster large-scale multinational company in agricultural trade, particularly that gathering research, production and sale, and popularizing high-tech agriculture, so as to compete with international agricultural multinational corporations in scale and financing.

\section{REFERENCES}

Araya, A., Girma, A., \& Getachew, F. (2015). Exploring Impacts of Climate Change on Maize Yield in Two Contrasting AgroEcologies of Ethiopia. Asian Journal Of Applied Science And Engineering, 4(1), 26-36.

Awan, A. (2013). China's Economic Growth - 21st Century Puzzle. Global Disclosure of Economics and Business, 2(2), 76-96. Retrieved from http://iproclaim.my/archive/index.php/gdeb/article/view/138

Bureau of Statistics, the State Administration of Foreign Exchange

Chhani, L. (2016). The Potential Impact of AEC 2015 on the Small Farmers of Myanmar. Asian Business Review, 6(2), 91-96. doi:http://dx.doi.org/10.18034/abr.v6i2.852

China Statistical Yearbook 2010

China's Ministry of Land and Resources in 2008

Guangdong Provincial Social Science Fund Project (09E-17)

Hajirostamlo, B., Mirsaeedghazi, N., Arefnia, M., Shariati, M., \& Fard, E. (2015). The Role of Research and Development in Agriculture and Its Dependent Concepts in Agriculture. Asian Journal Of Applied Science And Engineering, 4(1), 78-80.

Islam, M. (2013). Agricultural Adaptation to Climate Change: Issues for Developing Countries. Global Disclosure of Economics and Business, 2(2), 97-108. Retrieved from http://iproclaim.my/archive/index.php/gdeb/article/view/139

OECD website database, "Review of World Water Resources by Country", FAO, 2013

Rahman, M., \& Ahsan, M. (2015). Foreign Direct Investment as an Instrument for promoting Economic Development in Bangladesh. Asian Business Review, 3(4), 100-107. doi:http://dx.doi.org/10.18034/abr.v3i4.285

Raihana, B. (2015). Trend in Productivity research in Bangladesh Agriculture: A Review of selected Articles. Asian Business Review, 1(1), 01-04. doi:http://dx.doi.org/10.18034/abr.v1i1.329

Statistical Bulletin of Foreign Direct Investment (2008, 2009), published by Ministry of Commerce, P, R. China

WTO official website, 2010

\section{ACKNOWLEDGEMENT}

This paper is initial results of China National Social Science Fund Project (08 \& ZD030), National Natural Science Foundation of China (70873043), Guangdong Provincial Social Science Fund Project (09E-17), National Excellent Doctoral Dissertation Grant (200783). The author thanks the help of Ms. CHEN Shan-ni and Dr Tan Yan-wen

\section{SOCIAL SCIENCE RESEARCH NETWORK 2171 Monroe Avenue, Suite 203, Rochester, NY 14618, USA http://www.ssrn.com/en/}

AJTP Link: http://www.ssrn.com/link/American-Journal-Trade-Policy.html 